
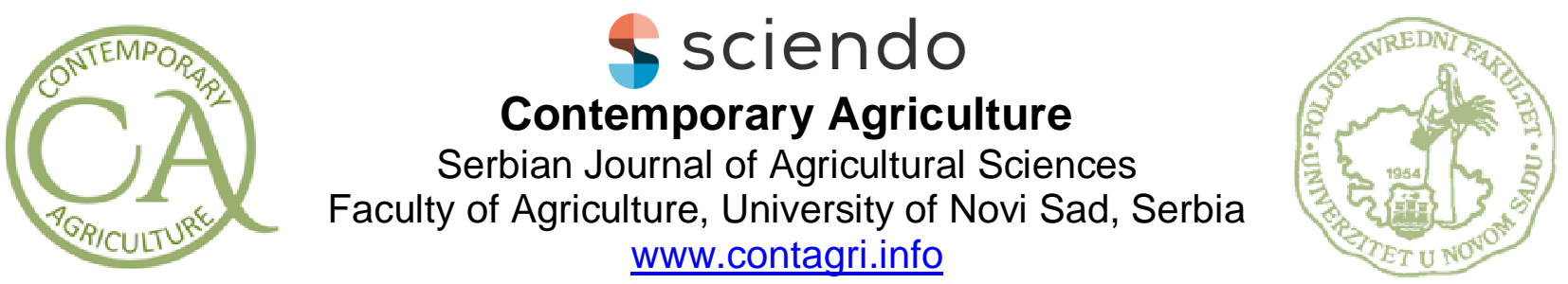

Original scientific paper

UDC: 641.12

DOI: $10.2478 /$ contagri-2021-0014

\title{
INFLUENCE OF TOTAL PRODUCTION ON THE PLANTING STRUCTURE OF SIGNIFICANT VEGETABLE CROPS IN THE REPUBLIC OF SERBIA
}

\author{
DRAGANA TEKIĆ ${ }^{*}$, NEBOJŠA NOVKOVIĆ ${ }^{l}$, BEBA MUTAVDŽIĆ' , MAJA POKUŠEVSKI \\ TIHOMIR ZORANOVIĆ \\ ${ }^{1}$ Faculty of Agriculture, University of Novi Sad, Trg Dositeja Obradovića 8, 21000 Novi Sad, Serbia \\ ${ }^{2}$ University Center of Applied Statistics, University of Novi Sad, Master student, Železnička 19, 21000 Novi \\ Sad, Serbia \\ *Corresponding author: tihomir@ polj.uns.ac.rs
}

\begin{abstract}
SUMMARY
The purpose of this paper is to examine, on the basis of the total production and distribution area parameters analyzed, a potential relationship between the actual production of major vegetable crops in Serbia in the current year and the following year's distribution of planting areas devoted to the crops considered. The analysis was performed for the period 2005-2019. The results obtained indicate that the current year's production of certain vegetable crops such as potatoes, cabbage, kale, peppers and beans affect the following year's distribution of their planting areas.
\end{abstract}

Key words: vegetables, production, planting area, Serbia, regression

\section{INTRODUCTION}

Plant production claims the largest share (approximately 70\%) of the total areas devoted to agricultural production in the Republic of Serbia, with field crops and vegetables accounting for more than 50\% of the total Serbian plant production. The focus of this paper will be on the vegetable production in Serbia as one of the most intensive branches of the Serbian plant production. From production, economic and agricultural perspectives, a further growth of the Serbian vegetable production is expected in the future (Mihajlović et al. 2019). According to Novković et al. (2018), the vegetable production in Serbia is characterized by the following features:

- a relatively short production process that allows two or more plantings of vegetables in the same year, thus leading to a significantly increased use of land,

- intensive production, i.e. large investments in irrigation and technology which generate higher yields,

- the need for organic fertilizer, which is essentially associated with livestock production, and

- high economic efficiency measured by the actual value of production and profit per unit of capacity, i.e. hectare.

A number of authors have analyzed the vegetable production in the Republic of Serbia. Mutavdžić et al. (2011) examined the vegetable production in Serbia in the period 2001-2010 with an emphasis on the areas, yields and production volumes of major vegetable crops such as tomatoes, peas, cabbage, kale, peppers, carrots, cucumbers, potatoes, onions, melons, watermelons and garlic. The results obtained unequivocally suggest that the total vegetable production in the Republic of Serbia shows increasing trends.

Ilin et al. (2014) report that the vegetable production in Serbia is one of the most intensive branches of the Serbian agriculture with an average annual production of 2.5 million tons and as much as 852 thousand tons of potatoes produced. Ivanišević (2015) analyzed and predicted the production and economic parameters of the Serbian vegetable production (the period considered for analysis was 1991-2010, whereas the forecast period was 2011- 
2015). Based on the results obtained it was concluded that a decrease in the areas devoted to vegetables was expected in the forecast period, accompanied with increases in both yields and total production volumes.

Novkovic et al. (2015) analyzed the vegetable production trends in the EU countries and the Republic of Serbia. The authors state that Serbia is one of the leading vegetable producers in Europe according to the areas devoted to vegetable production. However, Serbia falls behind in the yields of certain types of vegetables compared to the leading EU vegetable producing countries. On balance, all the researchers mentioned above have concluded that Serbia has a significant potential for vegetable production provided the intensity of vegetable production is increased and cotemporary agricultural and irrigation technologies are applied.

The purpose of this paper is to examine, on the basis of the total production and distribution area parameters analyzed, a potential relationship between the actual production of major vegetable crops in Serbia (namely potatoes, tomatoes, cabbage, kale, onions, peppers, beans, melons and watermelons) in the current year and the following year's distribution of planting areas devoted to the crops considered. The analysis was performed for the period 2005-2019.

It was hypothesized that vegetable producers were inclined to plan the following year's planting areas devoted to certain vegetables on the basis of their current year's actual production.

\section{MATERIAL AND METHODS}

Descriptive statistics and analytical methods were employed as appropriate to the objectives of this study (Nedeljković et al. 2019). Standard descriptive statistics tools were used for processing the parameter values observed. Annual rate of change values were computed to determine the relative change of all the variables analyzed in the period considered.

Regression analysis was employed to assess the effect of actual vegetable crop production in the current year on the following year's planting areas devoted to the respective vegetable crop. Regression analysis is used to discover the functional form-regression model (which is closest to the quantitative agreement between variations of the parameters observed), show how the dependent variable changes relative to independent variables, and assess and predict the behavior of the dependent variable according to the degree of parameter variation agreement. Regression analysis can also be defined as an assessment of the dependent variable according to one or more independent variables (Mutavdžić \& Nikolić- Đorić, 2018).

The applied regression model was of the following form: $Y=a+b X$. Y represents the dependent variable, i.e. the harvested area, $\mathrm{a}, \mathrm{b}$ are the parameters of regression, and $\mathrm{X}$ represents the independent variable, i.e. the total production.

The analysis performed involved the official data of the Statistical Office of the Republic of Serbia on the areas, yields and total production of major vegetable crops in Serbia in the period 2003-2019. The STATISTICA software package was used for statistical data processing.

\section{RESULTS AND DISCUSSION}

The average area devoted to vegetables in Serbia in the period considered was $156,523 \mathrm{ha}$, which is about $5 \%$ of the total arable land. On average, approximately 1.8 million tons of vegetables were produced in these relatively small areas. The basic descriptive statistics indicators for the production features of the respective vegetable crops considered are shown in Table 1.

Table 1. Descriptive statistics of vegetable production features in the Republic of Serbia (2005-2019)

\begin{tabular}{llccccc}
\hline Vegetable & $\begin{array}{c}\text { Production } \\
\text { features }\end{array}$ & Mean & Minimum & Maximum & $\begin{array}{c}\text { Coefficient of } \\
\text { variation (\%) }\end{array}$ & $\begin{array}{c}\text { Annual rate of } \\
\text { change (\%) }\end{array}$ \\
\hline Potato & Area (ha) & 48464.3 & 28232.0 & 58529.0 & 19.5 & -4.1 \\
& Yield (t/ha) & 15.3 & 11.0 & 20.0 & 14.9 & 2.0 \\
\multirow{5}{*}{ Tomato } & Production (t) & 748912.6 & 487909.0 & 969562.0 & 20.0 & -2.1 \\
& Area (ha) & 9378.5 & 7888.0 & 10917.0 & 7.5 & -1.0 \\
& Yield (t/ha) & 16.9 & 13.0 & 20.0 & 13.9 & -2.1 \\
Cabbage and and & Production (t) & 162915.5 & 111639.0 & 198677.0 & 15.6 & -3.1 \\
kale & Area (ha) & 11159.1 & 7957.0 & 12329.0 & 12.4 & -3.0 \\
& Yield (t/ha) & 24.7 & 22.0 & 27.0 & 7.6 & 0.1 \\
Onion & Production (t) & 281358.5 & 178308.0 & 336600.0 & 15.0 & -2.9 \\
& Area (ha) & 4841.2 & 334.0 & 5587.0 & 13.4 & -3.3 \\
& & & & & & \\
\hline
\end{tabular}




\begin{tabular}{|c|c|c|c|c|c|c|}
\hline & Yield (t/ha) & 7.3 & 6.0 & 12.0 & 20.5 & 1.9 \\
\hline & Production $(\mathrm{t})$ & 37342.6 & 27967.0 & 57880.0 & 20.5 & -1.4 \\
\hline \multirow[t]{3}{*}{ Pepper } & Area (ha) & 13066.9 & 10097.0 & 17386.0 & 14.9 & -1.8 \\
\hline & Yield (t/ha) & 9.1 & 7.0 & 13.0 & 20.3 & 2.8 \\
\hline & Production $(\mathrm{t})$ & 126358.6 & 88614.0 & 227645.0 & 31.7 & 1.0 \\
\hline \multirow[t]{3}{*}{ Beans } & Area (ha) & 12861.7 & 9091.0 & 15515.0 & 15.7 & -3.7 \\
\hline & Yield (t/ha) & 0.9 & 0.8 & 1.3 & 39.9 & -1.8 \\
\hline & Production $(\mathrm{t})$ & 14102.1 & 9027.0 & 20077.0 & 22.0 & -5.5 \\
\hline \multirow{3}{*}{$\begin{array}{l}\text { Melon and } \\
\text { watermelon }\end{array}$} & Area (ha) & 7313.0 & 5709.0 & 8617.0 & 11.9 & -2.9 \\
\hline & Yield (t/ha) & 30.3 & 25.0 & 37.0 & 11.2 & -0.7 \\
\hline & Production $(\mathrm{t})$ & 224565.7 & 163483.0 & 270898.0 & 13.3 & -3.6 \\
\hline
\end{tabular}

The planting areas of tomatoes, melons and watermelons show less variability than those of other vegetable crops considered. However, the planting areas of all the crops considered indicate downward trends. Of the observed vegetable crops, the largest areas are traditionally devoted to potatoes, but it should be taken into account that these areas are decreasing at the highest rate.

The vegetable yields recorded show significantly greater variability than the planting areas. In the period under consideration, the yields of beans (39.9\%), onions (20.5\%) and peppers (20.3\%) varied the most, whereas other types of vegetables showed less yield variability. The yields of potatoes, onions, cabbage, kale and pepper show increasing trends, whereas the yields of tomatoes, beans, melons and watermelons show slightly downward trends.

The total production volumes of all the crops considered in the period 2005-2019 indicate significant variability and overall downward trends. The highest variability was recorded in the total bean production $(22 \%)$ in the period under consideration, with the highest rate of decline $(-5.5 \%)$. As shown in Table 1, all the crops considered, with the exception of peppers, indicate downward trends in the period under consideration.

The analysis performed confirmed the dependence between the total vegetable crop production in the current year and the following year's planting area devoted to the vegetable crop considered. The Table 2 results indicate a statistically significant dependence between the total current years' production of potatoes $(p<0.05)$ and the following year's distribution of the areas devoted to potatoes. The absolute values of the following year's planting areas devoted to respective vegetable crops are also in a positive correlation with the total vegetable crop production in the current year $(\mathrm{r}=0.81)$, which indicates that the increase in the current year's total production of a respective vegetable crop affects the increase in the following year's distribution of areas devoted to the vegetable crop considered. The coefficient of determination $\left(\mathrm{R}^{2}\right)$ computed indicates that $65.7 \%$ of the variability of the following year's planting areas devoted to a vegetable crop can be accounted for by the current year's total production of the crop.

Table 2. Regression model of dependence between the following year's planting areas and the current year's production of potatoes

\begin{tabular}{|c|c|c|c|c|c|c|}
\hline \multirow{3}{*}{$\begin{array}{l}\mathrm{N}=15 \\
\text { Intercept }\end{array}$} & \multicolumn{6}{|c|}{$\begin{array}{l}\text { Regression Summary for Dependent Variable: Planting areas of potatoes } \\
\qquad \mathrm{R}=0.810293 ; \mathrm{R}^{2}=0.6565747 \text {; Adjusted } \mathrm{R}^{2}=0.63015741 \\
\mathrm{~F}(1,13)=24.854 ; \mathrm{p}<0.00025 ; \text { Std. Error estimate: } 5752.7\end{array}$} \\
\hline & $\mathrm{b}^{*}$ & Std.Err. of $b^{*}$ & $\mathrm{~b}$ & Std. Err. of b & $t(13)$ & p-value \\
\hline & & & 11773.23 & 7508.127 & 1.568066 & 0.140877 \\
\hline $\begin{array}{l}\text { Production of } \\
\text { potato }\end{array}$ & 0.810293 & 0.162534 & 0.05 & 0.010 & 4.985373 & 0.000249 \\
\hline
\end{tabular}

The regression model which explains the dependence between planting areas (Y) and total production volumes (X) of potatoes (Tab. 3) is of the following form:

$$
Y_{i}=11773.23+0.810293 X_{i}
$$

The coefficient $\mathrm{b}$ in the presented regression model indicates that an increase in the current year's total potato production of 1 ton will increase the following year's potato planting areas by 0.81 ha.

The regression analysis results indicate that there is no statistically significant correlation between the total current year's tomato production and the following year's tomato planting areas ( $p>0.05$ ). The current year's tomato production accounted for only $8.6 \%\left(\mathrm{R}^{2}\right)$ of the following year's planting area variability. 
Table 3. Regression model of dependence between the following year's planting areas and the current year's production of tomatoes

\begin{tabular}{|c|c|c|c|c|c|c|}
\hline \multirow{3}{*}{$\begin{array}{l}\mathrm{N}=15 \\
\text { Intercept }\end{array}$} & \multicolumn{6}{|c|}{$\begin{array}{l}\text { Regression Summary for Dependent Variable: Planting areas of tomatoes } \\
\qquad=0.29388741 ; R^{2}=0.08636981 ; \text { Adjusted } R^{2}=0.1609056 \\
F(1,13)=1.2290 ; p<0.28770 ; \text { Std. Error estimate: } 697.60\end{array}$} \\
\hline & $\mathrm{b}^{*}$ & Std.Err. of $b^{*}$ & $\mathrm{~b}$ & Std. Err. of b & $\mathrm{t}(13)$ & p-value \\
\hline & & & 7775.559 & 1457.085 & 5.336378 & 0.000135 \\
\hline $\begin{array}{l}\text { Production of } \\
\text { tomato }\end{array}$ & 0.293887 & 0.265102 & 0.010 & 0.009 & 1.108581 & 0.287699 \\
\hline
\end{tabular}

The regression model of the dependence between planting areas $(\mathrm{Y})$ and total production volumes $(\mathrm{X})$ of cabbage and kale (Tab. 4) is of the following form:

$$
Y_{i}=1987.72+0.720409 X_{i}
$$

The regression analysis model confirms a significant impact of the total current year's cabbage and kale production on the following year's distribution of cabbage and kale planting areas $(\mathrm{p}<0.05)$. The correlation coefficient values obtained confirm the existence of a positive relationship between the total current year's cabbage and kale production and the following year's distribution of cabbage and kale planting areas $(r=0.72)$. A coefficient of determination of 51.9\% indicates that the variability of cabbage and kale planting area in the following year is largely explained by the current year's cabbage and kale production.

Table 4. Regression model of dependence between the following year's planting areas and the current year's production of cabbage and kale

\begin{tabular}{|c|c|c|c|c|c|c|}
\hline \multirow{3}{*}{$\begin{array}{l}\mathrm{N}=15 \\
\text { Intercept } \\
\text { Production } \\
\text { cabbage } \\
\text { kale }\end{array}$} & \multicolumn{6}{|c|}{$\begin{array}{l}\text { Regression Summary for Dependent Variable: Planting areas of cabbage and kale } \\
\qquad \mathrm{R}=0.72040882 ; \mathrm{R}^{2}=0.51898887 \text {; Adjusted } \mathrm{R}^{2}=0.48198801 \\
\mathrm{~F}(1,13)=14.026 ; \mathrm{p}<0.00245 ; \text { Std. Error estimate: } 998.34\end{array}$} \\
\hline & $\mathrm{b}^{*}$ & Std.Err. of $b^{*}$ & $\begin{array}{c}\mathrm{b} \\
1978.725\end{array}$ & $\begin{array}{c}\text { Std. Err. of b } \\
2464.756\end{array}$ & $\begin{array}{c}\mathrm{t}(13) \\
0.802808\end{array}$ & $\begin{array}{c}\mathrm{p} \text {-value } \\
0.436518\end{array}$ \\
\hline & 0.720409 & 0.192356 & 0.032 & 0.008 & 3.745184 & 0.002450 \\
\hline
\end{tabular}

According to the absolute values of planting areas and total production, no statistically significant correlation was found between the total current year's onion production and the following year's distribution of onion planting areas (p>0.05) (Tab. 5). The current year's onion production accounted for only 5.8\% $\left(R^{2}\right)$ of the following year's onion planting area variability.

Table 5. Regression model of dependence between the following year's planting areas and the current year's production of onions

\begin{tabular}{|c|c|c|c|c|c|c|}
\hline \multirow{4}{*}{$\begin{array}{l}\mathrm{N}=15 \\
\text { Intercept } \\
\text { Production of } \\
\text { onion }\end{array}$} & \multicolumn{6}{|c|}{$\begin{array}{l}\text { Regression Summary for Dependent Variable: Planting areas of onions } \\
\mathrm{R}=0.24059310 ; \mathrm{R}^{2}=0.05788504 ; \text { Adjusted } \mathrm{R}^{2}=0.0016547 \\
\mathrm{~F}(1,13)=0.79874 ; \mathrm{p}<0.38772 ; \text { Std. Error estimate: } 654.84\end{array}$} \\
\hline & $\mathrm{b}^{*}$ & Std.Err. of $b^{*}$ & $\mathrm{~b}$ & Std. Err. of b & $\mathrm{t}(13)$ & p-value \\
\hline & & & 4591.101 & 326.9529 & 14.04208 & 0.000000 \\
\hline & 0.240593 & 0.269203 & 0.006 & 0.0062 & 0.89372 & 0.387717 \\
\hline
\end{tabular}

As shown in Table 6, there is a statistically significant dependence between the total current year's pepper production and the following year's distribution of pepper planting areas ( $\mathrm{p}<0.05)$. The regression model is of the following form:

$Y_{i}=9545.06+0.567673 X_{i}$

The regression model results indicate that an increase in the current year's pepper production of 1 ton is expected to increase the following year's pepper planting areas by 0.57 ha. The absolute values of the following year's pepper planting areas are in a positive correlation with the total current year's pepper production $(r=0.57)$. 
Table 6. Regression model of dependence between the following year's planting areas and the current year's production of peppers

\begin{tabular}{|c|c|c|c|c|c|c|}
\hline \multirow{3}{*}{$\begin{array}{l}\mathrm{N}=15 \\
\text { Intercept }\end{array}$} & \multicolumn{6}{|c|}{$\begin{array}{l}\text { Regression Summary for Dependent Variable: Planting areas of peppers } \\
\qquad \mathrm{R}=0.56767266 ; \mathrm{R}^{2}=0.3222522 ; \text { Adjusted } \mathrm{R}^{2}=0.2701178 \\
\mathrm{~F}(1,13)=6.1812 ; \mathrm{p}<0.02729 ; \text { Std. Error estimate: } 1664.1\end{array}$} \\
\hline & $\mathrm{b}^{*}$ & Std.Err. of $b^{*}$ & $\mathrm{~b}$ & Std. Err. of b & $\mathrm{t}(13)$ & p-value \\
\hline & & & 9545.056 & 1480.273 & 6.448172 & 0.000022 \\
\hline $\begin{array}{l}\text { Production of } \\
\text { onion }\end{array}$ & 0.567673 & 0.228330 & 0.028 & 0.011 & 2.486197 & 0.027290 \\
\hline
\end{tabular}

The regression analysis performed confirmed a significant dependence between the total current year's bean production and the following year's distribution of bean planting areas $(\mathrm{p}<0.05)$ (Tab. 7). The estimated regression model is of the following form:

$$
Y_{i}=8002.04+0.695639 X_{i}
$$

The effect of the total current year's bean production on the increase in the following year's bean planting areas is $48.39 \%\left(\mathrm{R}^{2}=0.4839\right)$. The correlation coefficient between the observed parameters confirms the existence of a positive relationship. The regression coefficient values obtained confirm that an increase in the current year's bean production of 1 ton is expected to increase the following year's bean planting areas by 0.69 ha.

Table 7. Regression model of dependence between the following year's planting areas and the current year's production of beans

\begin{tabular}{|c|c|c|c|c|c|c|}
\hline \multirow{4}{*}{$\begin{array}{l}\mathrm{N}=15 \\
\text { Intercept } \\
\text { Production of } \\
\text { onion }\end{array}$} & \multicolumn{6}{|c|}{$\begin{array}{c}\text { Regression Summary for Dependent Variable: Planting areas of beans } \\
\mathrm{R}=0.69563909 ; \mathrm{R}^{2}=0.48391374 ; \text { Adjusted } \mathrm{R}^{2}=0.4442148 \\
\mathrm{~F}(1,13)=12.190 ; \mathrm{p}<0.00398 ; \text { Std. Error estimate: } 1507.2\end{array}$} \\
\hline & $\mathrm{b}^{*}$ & Std.Err. of $b^{*}$ & $\mathrm{~b}$ & Std. Err. of b & $\mathrm{t}(13)$ & p-value \\
\hline & & & 8002.036 & 1445.284 & 5.536653 & 0.000096 \\
\hline & 0.695639 & 0.199246 & 0.316 & 0.091 & 3.491359 & 0.003979 \\
\hline
\end{tabular}

The regression analysis results (Tab. 8) indicate that there is no statistically significant relationship between the total current year's melon and watermelon production and the following year's melon and watermelon planting areas.

Table 8. Regression model of dependence between the following year's planting areas and the current year's production of melons and watermelons

\begin{tabular}{|c|c|c|c|c|c|c|}
\hline \multirow{3}{*}{$\begin{array}{l}\mathrm{N}=15 \\
\text { Intercept }\end{array}$} & \multicolumn{6}{|c|}{$\begin{array}{l}\text { Regression Summary for Dependent Variable: Planting areas of melons and watermelons } \\
\qquad \mathrm{R}=0.32866893 ; \mathrm{R}^{2}=0.10802326 ; \text { Adjusted } \mathrm{R}^{2}=0.03940967 \\
\mathrm{~F}(1,13)=1.5744 ; \mathrm{p}<0.23166 ; \text { Std. Error estimate: } 850.7\end{array}$} \\
\hline & $\mathrm{b}^{*}$ & Std.Err. of $b^{*}$ & $\mathrm{~b}$ & Std. Err. of b & $\mathrm{t}(13)$ & p-value \\
\hline & & & 4810.840 & 2006.230 & 2.397950 & 0.032208 \\
\hline $\begin{array}{l}\text { Production of } \\
\text { onion }\end{array}$ & 0.328669 & 0.261942 & 0.011 & 0.009 & 1.254739 & 0.231663 \\
\hline
\end{tabular}

The current year's melon and watermelon production accounted for only $3.9 \%\left(\mathrm{R}^{2}\right)$ of the following year's melon and watermelon planting area variability.

\section{CONCLUSION}

In the period under consideration (2005-2019), a decrease was recorded in the areas devoted to all the vegetable crops examined. The greatest downward trend was observed in potatoes at an annual rate of $-4.1 \%$. The yields of most of the vegetable crops considered have shown increasing trends, which are insufficient to compensate for the decline in their planting areas and overall production. The greatest downward trend in production was observed in beans $(-5.5 \%)$.

The regression analysis results indicate dependence between the total current year's production of a vegetable crop and the following year's distribution of planting areas devoted to the vegetable crop. A statistically significant effect of the total current year's production on the following year's planting areas was determined in potatoes, cabbage, kale, peppers and beans, whereas no such effect was recorded in tomatoes, onions, melons and watermelons. The 
evaluated regression models showed that there is a positive relationship between the total current year's production of potatoes, cabbage, kale, peppers and beans and their following year's planting areas, i.e. an increase in the total current year's production of these vegetables in expected to increase their following year's planting areas.

\section{REFERENCES}

Ilin Ž., Gvozdenović Đ., Boćanski J., Novković N., Adamović B. (2014): Proizvodnja povrća u funkciji razvoja sela u Republici Srbiji. Zbornik radova naučnog skupa Perspektive razvoja sela, 17- 18.4.2013, Srpska akademija nauka i umetnosti, Beograd, 63-85.

Ivanišević D. (2015): Predviđanje proizvodno ekonomskih parametara u povrtarstvu u Srbiji. Doktorska disertacija, Poljoprivredni fakultet, Novi Sad

Mihajlović Š., Vukelić N., Novković N., Mutavdžić B. (2019): Vegetable prices in Serbia: Tendencies and forecasting. Ekonomika poljoprivrede, 66(2): 485-498.

Mutavdžić B., Novković N., Ivanišević D. (2011): Tendencije razvoja povrtarstva u Srbiji. Agroznanje, Univerzitet u Banja Luci, Poljoprivredni fakultet, 12(1): 23-31.

Mutavdžić B. \& Nikolić-Đorić E. (2018): Statistika. Poljoprivredni fakultet, Univerzitet u Novom Sadu.

Nedeljković M., Mutavdžić B., Zoranović T., Suzić R. (2019): Forecasting corn production in the Republic of Srpska. Ekonomika poljoprivrede, 66(3): 681-690.

Novkovic N., Mutavdžić B., Ilin, Ž., Lazić, D. (2015): Vegetables production tendencies in the EU countries - Introductory lecture. Book of Abstracts, IV International Symposium and XX Scientific Conference of Agronomists of Republic of Srpska, 161-162.

Novković N., Mutavdžić B.,Peševski M., Drinić Lj., Mihajlović Š. (2018): Proizvodna obeležja paprike u Srbiji, Makedoniji i Republici Srpskoj. Agroekonomika, Departman za ekonomiku poljoprivrede i sociologiju sela, Poljoprivredni fakultet, Univerzitet u Novom Sadu, 74: 21-28.

https://www.stat.gov.rs/ (accessed: 26.03.2020.)

Submitted: 11.11.2020.

Accepted: 19.02.2021. 